\title{
Gracillaria Associated Amphipod at Abalones' Rearing Tank, Lombok Marine Aquaculture Development Center, Sekotong, Indonesia
}

\author{
Amphipoda terkait Gracillaria pada Bak Pemeliharaan Abalon, Balai Budidaya Laut \\ Lombok, Sekotong, Indonesia
}

\author{
Felicia Zahida $^{1 *}$, Hery Setyabudi ${ }^{2}$, Wibowo N. Jati ${ }^{1}$ \\ ${ }^{1}$ Faculty of Technobiology, University of Atma Jaya Yogyakarta. Jl. Babarsari 44, Yogyakarta Indonesia \\ ${ }^{2}$ Lombok Marine Aquaculture Development Center. Sekotong, Nusa Tenggara Barat, Indonesia \\ E-mail: feliciazda@mail.uajy.ac.id* Penulis untuk korespondensi
}

\begin{abstract}
Some benthic minute amphipods have been found at abalones'rearing tank, at Lombok Marine Aquaculture Development Center, Sekotong, West Nusa Tenggara, Indonesia. The minute amphipod community was found along with Gracillaria verrucosa which was harvested from Sekotong fishpond. There is some vigilance that it might be a pest that interferes the production of abalones. This research aims to reveal the type of the minute amphipod at the rearing tank. Morphological characters were examined to identify the Amphipod. Some slide was made to recognise and identify minute apparatus of the Amphipod. A hundred of Amphipod was reared in a small container to see their immediate behavior such as feeding or reproduction or other/s or its product. Some video were used to record for 30" to 60" to see the behavior of Amphipods. Result show that at least four types of Gammaridea present at the abalone culture pond. Some Amphipod was descent to abalone for some time, hop and perch to Gracillaria. Some Amphipods build a nest from pieces of Gracillaria in a tube form. There are two types of nest, firstly, small tube which were attached to the substrate and secondly, bigger tube which were float with the Gracillaria.
\end{abstract}

Keywords: Gammaridea, tube-dwelling, Gracillaria-associated

\begin{abstract}
Abstrak
Amphipoda kecil bentik telah diketemukan pada bak pemeliharaan abalon, Balai Budidaya Laut Lombok, Sekotong, Nusa Tenggara Barat, Indonesia. Komunitas amphipoda kecil ini diketemukan bersama Gracillaria verrucosa yang dipanen dari tambak Sekotong. Ada kekhawatiran bahwa mereka ini kemungkinan adalah hama yang dapat mengganggu produksi abalone. Penelitian ini bertujuan untuk mengungkapkan tipe amphipoda kecil yang ditemukan pada bak pemeliharaan tersebut. Karakter morfologi dipelajari untuk mengidentifikasi Amphipoda. Beberapa slide dibuat untuk mengenali mengidentifikasi bagian asesoris Amphipoda. Seratus Amphipoda dipelihara di bak kecil untuk mempelajari perilakunya secara cepat seperti perilaku makan atau reproduksi atau perilaku lain atau produknya. Beberapa video digunakan untuk merekam selama 30" hingga 60" untuk melihat perilaku Amphipod. Hasil memperlihatkan bahwa terdapat setidaknya empat tipe Gammarida pada bak pemeliharaan abalone. Beberapa Amphipoda bertengger ke abalon sementara waktu untuk kemudian melompat hinggap di Gracillaria. Beberapa Amphipoda membangun sarang dari serpihan Gracillaria dalam bentuk tabung. Ada dua tipe sarang tabung, pertama tabung kecil yang menempel di dasar bak, dan tabung besar yang terapung bersama Gracillaria.
\end{abstract}

Kata kunci: Gammaridea, penghuni sarang tabung, asosiasi dengan Gracillaria

Diterima: 16 Juli 2016, disetujui: 5 September 2016

\section{Introduction}

Some benthic minute amphipods have been found at abalones'rearing tank, at
Lombok Marine Aquaculture Development Center, Sekotong, West Nusa Tenggara, Indonesia. The minute amphipod community was found along with Gracillaria sp which 
was harvested from Sekotong fishpond. There is some vigilance that it might be a pest that interferes the production of abalones. This research aims to reveal the type of the minute amphipod at the rearing tank.

\section{Research Methods}

Amphipod's sampling was done by hand picking, and preservation was done using alcohol 70\%. Microscope binocular stereo (Euromex model KTD 36778), inverted microscope (XDS-2 Series), micro-dissecting kit, Syracuse dish, needles, concave glass slide, cover slip, glycerin, Canada balsam, and underwater camera Nikon Coolpix AW 130. Morphological characters were examine following Barnard \& Karaman (1991) to identify the Amphipod. Some slide was made to recognise and identify minute apparatus of the Amphipod. A hundred of Amphipod was reared in a small container to see their immediate behavior (feeding or reproduction behavior or other/s) or its product. Some video were used to record for 30 " to 60 " to see behavior of Amphipods.

\section{Limitation of Study}

Observation of behavior was limited only on day hours, no observation was done at night because of the regulation at Lombok Marine Aquaculture Development Center.

\section{Results and Discussion}

At least four kinds of Amphipods were found at Abalone rearing tank: First Gammarid has quite big strong gnatopod and short antennae, Second Gammarid has bigger gnatopod and longer antennae, Third Gammarid specimen has an elongated slim gnatopod, Fourth Gammarid specimen has big gnatopod and an elongated widen coxae.

One out of four kinds of that Amphipod (Figure 1) has been chosen randomly to be observed in detail for its morphology. Description of that amphipod is as follows. The general segments was following characters of Gammaridea with the possession of three pair of pleopods (swimmerets) and three pairs of uropods on pleon (abdomen). No ornamentation such as teeth on dorsal and lateral pereon, no spine on dorsal specifically on pleon, and no elongation of metasoma. The size was normal like basic Gammaridea, 1-4 segments have medium length, 5-7 segments have shorter and smaller length. Coxae sub quadrate, overlapping like stack of tiles. Head has a size as a function of one pereonite, shape as normal Gammaridea (cuboidal). No rostrum appeared. Eyes presence, and occupy anterior surface of head.

Obviously seen that the first antenna were shorter than second antenna. Eyes were obviously seen. Pigmentation of the eyes is strong. Coxae were rounded, and overlapping. First coxae were trust forward, the second one were the smallest. Forth were on top position. First gnatopod was small and the second gnatopod were big and strong. Size ratio of first and second gnatopod was about 1: 10.

Figure 3 and 4 showed the middle and posterior part of the gammarid. Proximal to middle part was marked by gnatopod 1, gnatopod 2, and pereopod (walking legs) 3-7, posterior part was marked by pleopods 1-3, and uropod 1-3. A male appendage which is important for reproduction usually present at seventh pereonite. It is appear as small pair of projection at the sternite. No male appendages visible (Figure 1) in this case.

Coxae which are actually a sideplates are like an extension of segment and very important for identification. Shape of first coxae is projecting proximal shielding the ventral head. The second and subsequent coxae are quadratic to round in shape. Anterior part of coxae cover porterior part of the front coxae. The sizes of coxae are proportional to the size of corresponding segment, bigger to posterior. 
Felicia Zahida et al.,

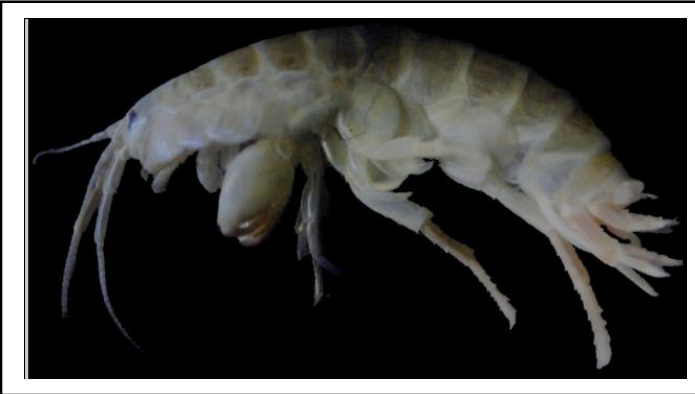

Figure 1. First Gammarid has quite big and strong gnatopod and shorter antennae. First antennae are shorter than the second antennae.

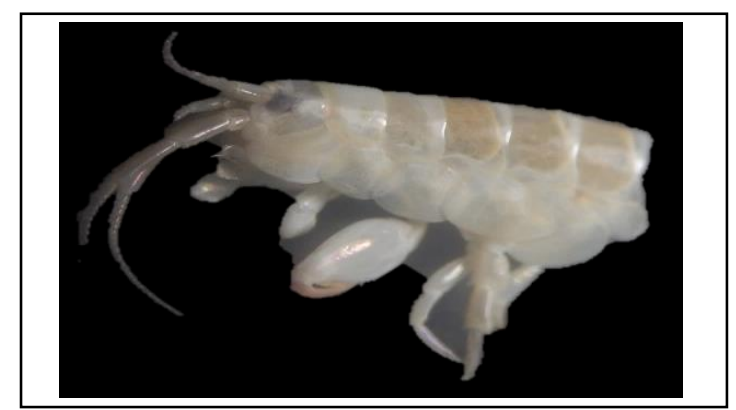

Figure 2. Anterior part of gammaridea show two pair of antennae, eyes, and some anterior legs

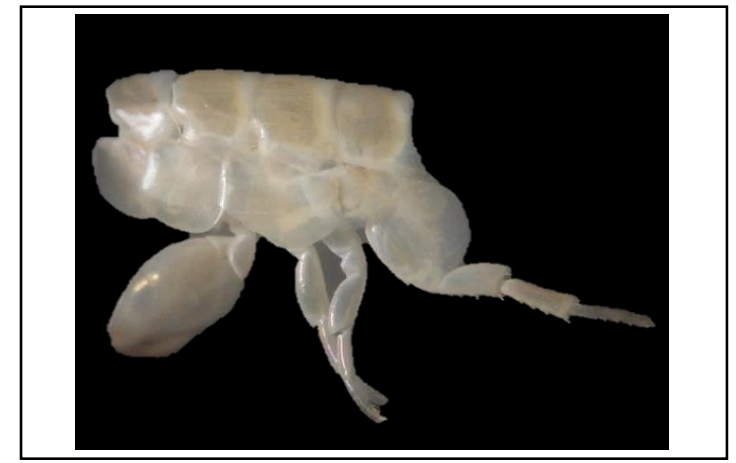

Figure 3. Middle part of Gammaridea show second gnatopod, and pereopod 3, 4, and 5

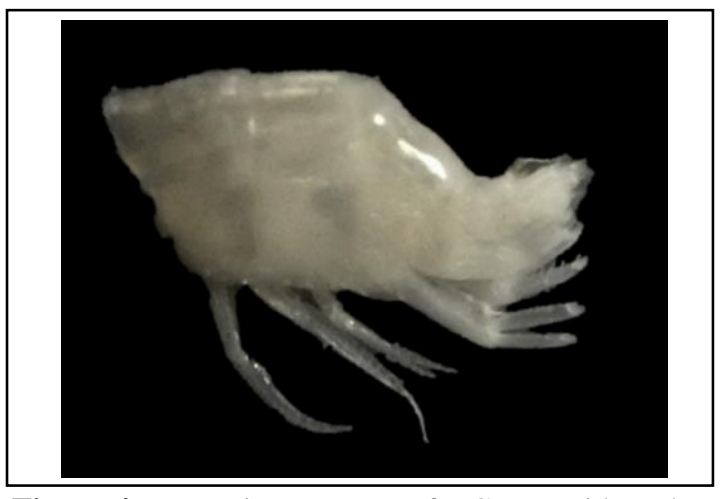

Figure 4. Posterior parts of Gammarida show pleopod 1, 2, 3, and uropod 1, 2, 3 


\section{Taxonomy of Gammaridea}

Amphipoda classification is as follows: Class Malacostraca (Latreille, 1802), Sub Class Eumalacostraca (Grobben, 1892), Super Order Peracarida (Calman, 1904), Order Amphipoda (Lattreille, 1816). Indonesia have 106 species of Amphipoda. This order have two sub order: Sub Order Gammaridea and Senticauda. Indonesia have 30 species of sub order Gammaridea (Lattreille, 1802) so far, and for sub order Senticauda (Lowry and Myers, 2013) Indonesia have two species of Talitridae, i.e. Floresorchestia floresiana (Weber 1892) and Talitroides topitotum (Burt, 1934) (Daneliya and Wowor, (2016). Only seven species recognized at Southeast Asia so far (Insectoid info, 2016), i.e. Floresorchestia florensiana (Weber 1892), Parorchestia kinabaluensis (Soemaker, 1935), Talitrus curioi (Javier and Coleman, 2010), Talorchestia mindorensis (Olerod, 1970), Talorchestia palawensis (Morino and Miyamoto, 1988), Talorchestia pravidactyla (Haswell, 1880), and Talorschestia spinipalma (Dana, 1853).

Specimen identification so far nearest to family Talitridae. Identification to genus and species need some more detail to be observed.

\section{Nest of Amphipods}

Barnard and Karaman (1991) stated that there are six to seven families of Amphipods building tube nests. i.e. genera Ischyroceridae, Corophiidae, Amphithoidae, Phoxocephalids, Haustoriids, and Argissids. In this research, nest of Amphipods has been found among abalone's food, Gracillaria. There are two types of nests found, first was small, attached to the bottom of container and tube form. Second nest was bigger, floating with Gracillaria colony.

Talitridae was not in Bernard \& Karaman (1991) list, while the nearest identification was in that grup. Fact show that among four species found makes Gracillaria nest. This might be a new record of tube dwelling Talitridae.

There are at least two types of nest, but not clear yet which species made those nests. Bernard \& Karaman (1991) stated that six or seven families of amphipod, construct dwelling tubes i.e. genera Ischyroceridae, Corophiidae, Amphithoidae, Phoxocephalids, Haustoriids, and Argissids.

50 gr Gracillaria was placed to the container (about 45 lt.) contained 5 abalones. A hundred amphipods were introduced to the same container to see immediate interaction between them. Amphipods were gathered around Gracillaria. Some were stop by on the shells of abalones but do not bother the abalones. Obviously amphipod only ate Gracillaria.

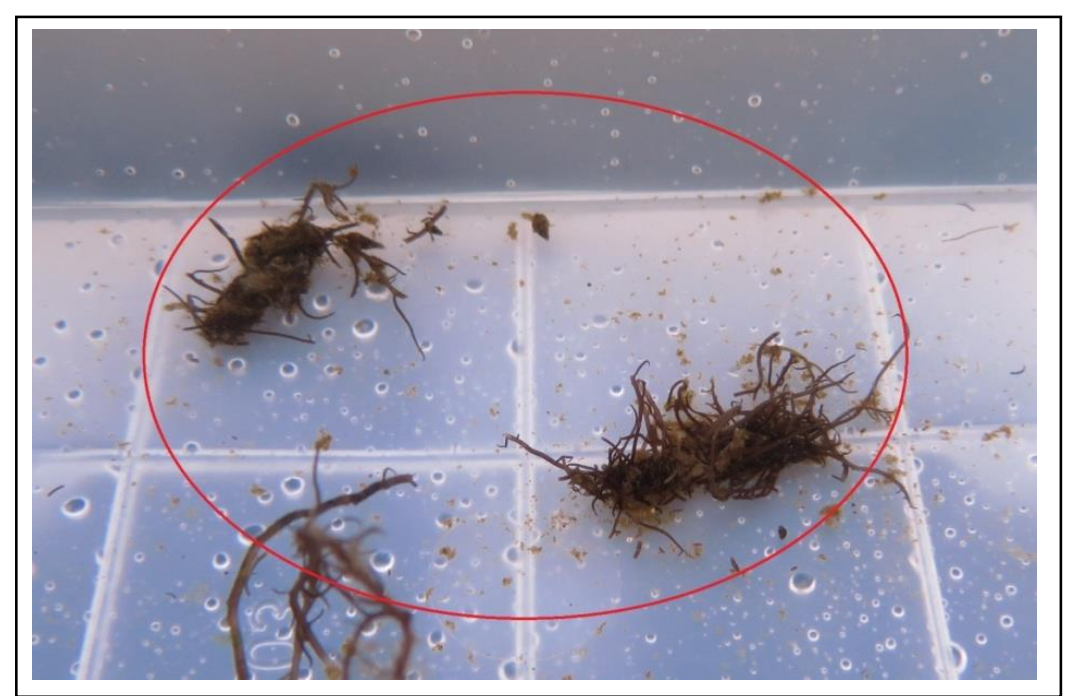

Figure 5. Nest type 1: forms tube, small, attached at the bottom of the container, made from Gracillaria. 


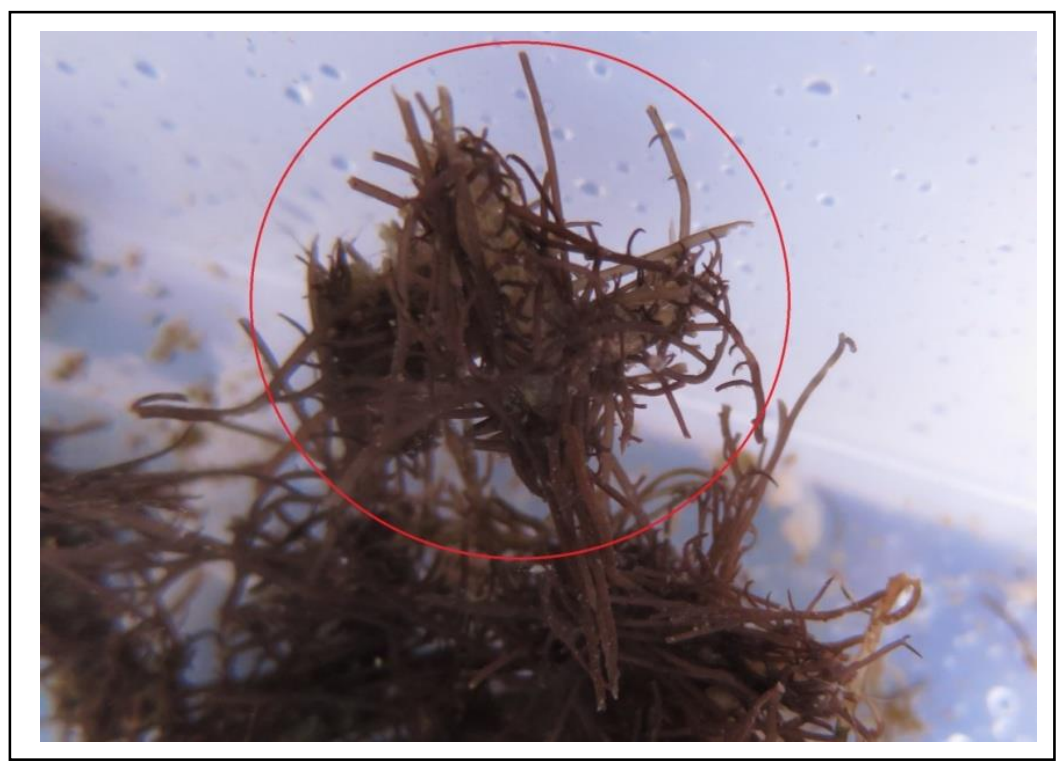

Figure 6. Nest type 2: much bigger, floating with the Gracillaria's colonies.

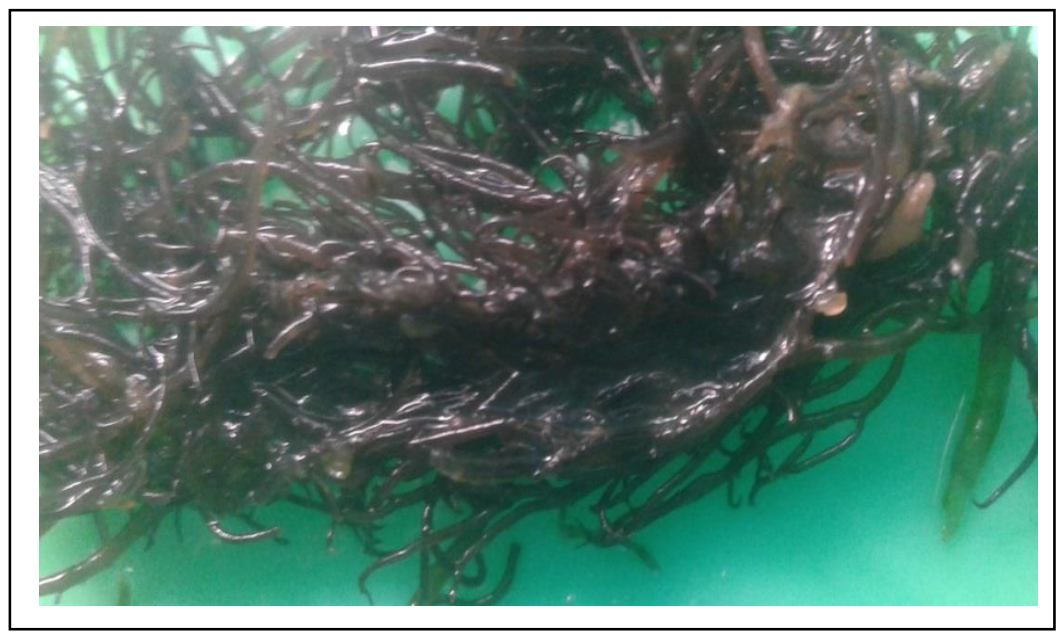

Figure 7. An opened nest type 2 is showing the material secreted from the body of Amphipod.

\section{Conclusion}

Amphipods stay in abalone's tanks was more than one species. They build a tube nests. One of them attached to the bottom and the second one was floating with the Gracillaria verrucosa. Identification of Amphipods showed that they are including to the order Gammaridea. One of the species is include in family Talitridae. Further identification are needed to verify the species name.

\section{Acknowledgements}

This worked was funded by Ristek-Dikti for under Fundamental Research scheme year 2016-2017. I would like to express my very great appreciation to Lombok Marine Aquaculture Development Center. Sekotong, Nusa Tenggara Barat specifically to Mr. Hery Setiabudi for his assistance during research. Great thanks to LPPM UAJY. Thanks to my student Yunice Femilia Bandue for taking a picture of opened tube of Gracillaria. 


\section{References}

Bernard, J. and Karaman, G. 1991. The families and genera of marine Gammaridean Amphipoda (except marine gammaroid). Rec. Aust. Mus. Suppl., 13: 1-866.

Chapman, J.W. 2007. Amphipoda Key to Amphipoda Gammaridea. In J.W. Chapman, Amphipoda Key to Amphipoda Gammaridea (pp. 545-618). Oregon: Techbooks (PPG Quark).

Daneliya, Mikail, E. and Daisy, W. 2016. Cosmopolitan Landhopper Talitroides topitotum (Crustacea, Amphipoda, Talitridae) in Java, Indonesia. Check List 12 (4): 1933, 23 July 2016 doi: http://dx.doi.org/10.15560/12.4.1933 ISSN 1809-127X
Lowry, J. and Stoddart, H. 2003. Crustacea: Malacostraca: Peracarida: Amphipoda, Cumacea, Mysidacea. In Beesley, P.L. \& Houston, W.W.K. (eds). Zoological Cataloque of Australia. Vol. 19.2B. Melbourne: CSIRO Publishing, Australia xii $531 \mathrm{pp}$.

Phillips, C. and Wendt, D. 2006. A Visual Identification Guide to the Gammaridean Amphipods Morro Bay, CA, Order Amphipoda, Sub Order Gammaridea. Obispo: California Polytechnic State University San Luis Obispo. Insectoid.info/checklist/gammaridea/Indonesia/ download date 13-17/08/2016. 